\title{
Penerapan Prinsip-Prinsip Good Governance Dalam Pengelolaan Dana Desa Di Desa Wlahar Wetan Kecamatan Kalibagor Kabupaten Banyumas
}

\section{Maharani Mufti Rahajeng}

Mahasiswa Program Studi Magister Administrasi Publik, FISIP, Universitas Jenderal Soedirman Email: maharanirahajeng@gmail.com

\begin{abstract}
Abstrak
Prinsip-prinsip good governance berperan untuk menciptakan pemerintahan yang bersih dan mewujudkan kesejahteraan masyarakat. Good governance merupakan salah satu bagian dari isu kebijakan strategis yang digunakan untuk memperbaiki kinerja instansi pemerintah. Setiap aktivitas pada instansi pemerintah dapat mengaplikasikan konsep good governance, begitu juga dalam mengelola Dana Desa. Dana Desa nominalnya selalu mengalami kenaikan sehingga tidak mudah dikelola begitu juga di Kabupaten Banyumas. Penerapan prinsip-prinsip good governance seperti akuntabilitas, transparansi, dan partisipasi dalam pengelolaan Dana Desa menjadi prioritas termasuk Desa Wlahar Wetan. Tujuan penelitian ini adalah untuk menganalisis sejauh mana penerapan prinsip-prinsip akuntabilitas, transparansi, dan partisipasi dalam mewujudkan good governance dalam pengelolaan Dana Desa di Desa Wlahar Wetan Kecamatan Kalibagor Kabupaten Banyumas. Metode penelitian menggunakan metode kualitatif dengan teknik analisis data yaitu analisis data interaktif. Hasil penelitian menunjukan Pemerintah Desa Wlahar Wetan tertib dan tepat waktu dalam melaporkan laporan pertanggungjawaban penggunaan Dana Desa baik secara vertikal kepada Pemerintah Pusat dan Daerah kemudian secara horizontal kepada masyarakat. Penilaian terhadap pelaksanaan akuntabilitas Dana Desa masih sebatas melihat ketepatan waktu belum mengawasi perencanaan, pelaksanaan, evaluasi. Sanksi yang diterapkan juga belum tegas. Kemudian, komitmen Pemerintah Desa Wlahar Wetan untuk terbuka terhadap segala informasi Dana Desa ditunjukan dengan menyediakan media transparansi yang mudah diakses oleh masyarakat baik di desa maupun puar desa. Namun, infromasinya baru mengenai anggaran dan realisasi, belum sampai pada dampak kegiatan. Selanjutnya, Pemerintah Desa Wlahar Wetan turut melibatkan masyarakat dalam tahapan perencanaan dan pelaksanaan kegiatan yang menggunakan Dana Desa dengan prinsip swakelola. Tetapi Pemerintah Desa belum melibatkan masyarakat dalam tahapan evaluasi bersama.
\end{abstract}

Kata Kunci: Dana Desa, Good Governance, Prinsip-Prinsip Good Governance.

\begin{abstract}
The principles of good governance embody to create clean government and realize community welfare. Good governance is one part of the strategic policy issues used to improve government affairs. Every activity in the government can apply the concept of good governance, as well as in managing the Village Fund. The nominal Village Fund continues to increase so it is not easy to manage also in Banyumas Regency. The application of good governance principles such as accountability, approval, and participation in the management of Village Funds is a priority including Wlahar Wetan Village. The purpose of this study was to analyze the application of the principles of accountability, approval, and participation in realizing good governance in the management of the Village Fund in Wlahar Wetan Village, Kalibagor District, Banyumas Regency. The research method uses qualitative methods with data analysis techniques namely interactive data analysis. The results showed the Wlahar Wetan Village Government was orderly and timely in reporting accountability for the use of Village Funds both vertically to the Central and Regional Governments and then horizontally to the community. Evaluation of the implementation of Village Fund accountability is still limited to seeing the timeliness
\end{abstract}


of planning, implementation, evaluation. Sanctions have not yet been confirmed. Then, the commitment of the Wlahar Wetan Village Government to open up all information. The Village Fund is handled by providing media that facilitates access by the community both in the village and in the village. However, only about the budget and realization, has not reached the activity. Furthermore, the Wlahar Wetan Village Government participates in the community in planning and implementing activities that use the Village Fund with the principle of self-management. However, the Village Government has not yet involved the community.

Keywords: Good Governance, The Principles of Good Governance, Village Funds.

\section{PENDAHULUAN}

Istilah good governance seringkali disebut tata kelola yang baik dalam pemerintahan untuk menyelenggarakan kesejahteraan. Dalam pelaksanaannya, prinsip good governance di setiap penyelanggaraan pemerintahan berperan untuk menciptakan pemerintahan yang bersih. Setiap aktivitas pada instansi pemerintah dapat senantiasa mengaplikasikan konsep good governance, begitu juga dalam pengelolaan Dana Desa oleh Pemerintah Desa. Dana Desa dalam pengelolaannya juga harus punya tata kelola yang baik. Hal ini menjadi penting karena Dana Desa selain menguntungkan untuk pembangunan tetapi jika tidak dikelola dengan baik bisa terjadi penyelewengan-penyelewengan salah satunya tindakan korupsi. Oleh karena itu, Pemerintah Desa harus mampu memahami bagaimana tata cara mengelola keuangan yang baik. Relevan dengan hal ini, maka konsep good governance dapat diaplikasikan di dalam pengelolaan Dana Desa dengan menerapkan prinsip-prinsip good governance.

Munculnya kebijakan Dana Desa sebagai salah satu sumber pendapatan desa merupakan bentuk realisasi dari janji dan harapan pemerintah pusat untuk mewujudkan pembangunan yang merata sampai ke pelosok desa dimana sebelumnya krisis pembangunan telah terjadi di desa karena pembangunan di desa yang belum mandiri. Di dalam UU No. 6 Tahun 2014 Tentang Desa telah diatur sumber pendanaan bagi desa yang berjumlah 73.000 desa dimana dana ini berasal dari Anggaran Pendapatan dan Belanja Negara (APBN) dengan jumlah yang jauh di atas jumlah pendapatan yang ada di desa bahkan bisa mencapai satu miliar untuk masing-masing desa yang kemudian disebut dengan Dana Desa (DD). Dalam rangka mendukung otonomi desa dan desentralisasi pembangunan di desa, Pemerintah Pusat memberikan jaminan pasti dengan mengalokasikan Dana Desa sebesar 10\% dari APBN yang digunakan untuk pembiayaan Pemerintah Desa dalam menyelenggarakan pemerintahan desa, pembangunan desa, membina kemasyarakatan, dan kegiatan pemberdayaan masyarakat. Pengelolaan Dana Desa ini ditindaklanjuti dengan Peraturan Menteri Dalam Negeri No. 20 Tahun 2018 Tentang Pengelolaan Keuangan Desa dan PP No. 60 Tahun 2014 Tentang Dana Desa yang bersumber dari APBN. Di dalam PP No. 60 Tahun 2014 Tentang Dana Desa yang Bersumber dari APBN ditetapkan besaran Dana Desa untuk setiap desa yang dihitung 
berdasarkan jumlah penduduk desa (30\%), luas wilayah desa (20\%), angka kemiskinan desa (50\%), dan tingkat kesulitan geografis untuk kemudian ditetapkan ke dalam APBN.

Menurut hasil studi Rustiarini (2016) dengan adanya Dana Desa sebagai salah satu sumber pendapatan desa maka Pemerintah Desa diharapkan memiliki kemampuan dalam melaksanakan pembangunan sesuai dengan prioritas yang menjadi kebutuhan masyarakat, kemudian masalah yang dihadapi cepat ditanggapi, aspirasi masyarakat dapat terserap dengan baik serta mampu memanfaatkan potensi yang dimiliki desa. Namun, dibalik dampak positif yang diharapkan berkembang pula kekhawatiran mengenai dampak negatif yang akan muncul. Munculnya praktik korupsi dalam pengelolaan Dana Desa di tingkat desa menjadi persoalan sangat mengkhawatirkan sejak diturunkannya kebijakan Dana Desa ini. Hal ini mengingat jumlah Dana Desa yang cukup besar dan kesiapan sumber daya manusia yaitu Perangkat Desa dalam mengelolanya. Peringatan mengenai penyalahgunaan Dana Desa sudah muncul sedari awal dari berbagai pihak. Pengelolaan Dana Desa yang dilakukan saat ini cenderung menjadi lahan yang baru bagi oknum di dalam Pemerintah Desa.

Adanya permasalahan dalam pengelolaan Dana Desa menunjukkan pentingnya good governance dalam tata kelola keuangan desa. Hasil studi yang dilakukan Rustiarini (2016) menyatakan pengelolaan keuangan dengan good governance terbukti telah banyak membawa dampak yang positif bagi tata kelola pemerintahan. Melihat pentingnya penerapan prinsip good governance ini menjadikan prinsip good governance sebaiknya dapat diaplikasikan di setiap sektor pemerintahan termasuk sektor keuangan publik di tingkat desa dengan memperhatikan agenda kebijakan pemerintah.

Sedarmayanti (2012: 7) menyimpulkan bahwa prinsip akuntabilitas, transparansi, dan partisipasi merupakan prinsip utama yang dapat memberi gambaran administrasi publik yang bercirikan good governance. Hal ini sejalan dengan Peraturan Menteri Dalam Negeri Republik Indonesia Nomor 20 Tahun 2018 Tentang Pengelolaan Keuangan Desa yang menuliskan bahwa keuangan desa harus dikelola berdasarkan asas-asas transparan, akuntabel, partisipatif serta dilakukan dengan tertib dan disiplin anggaran. Perkembangan Dana Desa dari awal kemunculannya pada tahun 2015 sampai sekarang tahun 2019 selalu naik bahkan di tahun 2020 nanti diperkirakan lebih dari 70 Triliyun, seperti yang tertulis pada tabel besaran Dana Desa dari tahun 2015-2019 sebagai berikut:

Tabel 1. Besaran Dana Desa 2015-2019 (s.d. 30 Juni 2019)

\begin{tabular}{lccccc}
\hline & $\mathbf{2 0 1 5}$ & $\mathbf{2 0 1 6}$ & $\mathbf{2 0 1 7}$ & $\mathbf{2 0 1 8}$ & $\mathbf{2 0 1 9}$ \\
\hline Nasional & Rp 20,77 T & Rp 46,68 T & Rp 59,77 T & Rp 60 T & 70 T \\
Prov. Jateng & 74.093 Desa & 74.754 Desa & 74.954 Desa & 74.957 Desa & 74.954 Desa \\
& Rp 2,23 T & Rp 5,00 T & Rp 6,38 T & Rp 6,73 T & Rp 7,89 T \\
Kab. & 7.809 Desa & 7.809 Desa & 7.809 Desa & 7.809 Desa & 7.809 Desa \\
Banyumas & Rp 89,29M & Rp 200,45T & Rp 255,73M & Rp 295,87M & Rp 360,74M \\
& 301 Desa & 301 Desa & 301 Desa & 301 Desa & 301 Desa \\
\hline
\end{tabular}

Sumber: Badan Pengawasan Keuangan dan Pembangunan Provinsi Jateng 
Di Kabupaten Banyumas terdapat 27 kecamatan tetapi yang mendapatkan aliran Dana Desa adalah 301 desa yang terbagi dalam 23 wilayah kecamatan. Kemudian, di Kabupaten Banyumas sendiri Dana Desa sudah naik sebanyak 4 kali lipat selama kurun waktu 4 tahun dari 2015 hingga tahun 2019 sehingga kurang lebih setiap desa di Kabupaten Banyumas yang berjumlah 301 desa ini menerima masing-masing Rp 1 Miliar. Jumlah ini tentu tidak kecil dan tidak mudah untuk dikelola oleh desa sehingga akuntabilitas Dana Desa menjadi prioritas baik secara vertikal maupun horizontal karena jumlahnya yang sangat besar diikuti dengan adanya transparansi, dan partisipasi masyarakat dalam pengelolaannya tetapi sumber daya di desa dianggap belum mampu untuk mengelolanya.

Hasil pra survei yang dilakukan oleh peneliti dengan dengan salah satu informan dari Dinas Sosial dan Pemberdayaan Masyarakat Desa Kabupaten Banyumas memberikan pernyataan bahwa ternyata tidak semua desa di Kabupaten Banyumas mau untuk diberikan pembinaan dan pelatihan dalam pengelolaan Dana Desa yang lebih optimal karena terkadang mereka sudah merasa tidak mampu lebih dahulu sehingga menolak. Di Kabupaten Banyumas terdapat salah satu desa yang senantiasa mendukung terwujudnya good governance di Pemerintahan Desa yaitu Desa Wlahar Wetan melalui Visi Desa yang ingin "Mewujudkan Desa Wlahar Wetan yang Sejahtera dan Berbudaya Menuju Kemandirian Kelembagaan Kemasyarakatan Desa serta Tercapainya Good Local Governance dan Clean Government. Desa Wlahar Wetan yang masuk dalam wilayah Kecamatan Kalibagor Kabupaten Banyumas termasuk dalam 301 desa di Kabupaten Banyumas yang turut menerima Dana Desa. Berdasarkan hasil rekapitulasi dan perbandingan peringkat Indeks Desa Membangun (IDM) tahun 2017-2019, Desa Wlahar Wetan besaran indeksnya terus meningkat hingga tahun 2019 dan berhasil menyandang status sebagai desa maju, hal ini bisa dilihat pada data sebagai berikut:

Tabel 2. Hasil Rekapitulasi Indeks Desa Membangun (IDM) Desa Wlahar Wetan

\begin{tabular}{lccc}
\hline & $\mathbf{2 0 1 7}$ & $\mathbf{2 0 1 8}$ & $\mathbf{2 0 1 9}$ \\
\hline Indeks Ketahanan Sosial & 0.6114 & 0.691 & 0,7600 \\
Indeks Ketahanan Ekonomi & 0.65 & 0.683 & 0,7167 \\
Indeks Ketahanan Ekologi & & & 0,6667 \\
Nilai IDM & 0.6667 & 0.667 & 0,7144 \\
Status & 0.6427 & 0.687 & Maju \\
\hline
\end{tabular}

Sumber: Dinas Sosial dan Pemberdayaan Masyarakat Desa Kabupaten Banyumas

Menurut Dinas terkait penyebab IDM naik bisa jadi karena SDM Pemerintah Desa naik,

Dana Desa bidang pemberdayaan masyarakat meningkat dari tahun sebelumnya, warga miskin menurun, dan ada infrastruktur menuju ke ekonomi masyarakat. Desa Wlahar Wetan menjadi satu-satunya desa di Kecamatan Kalibagor yang besaran indeks dalam IDM terus meningkat hingga menjadi desa maju. Penilaian dalam IDM ini berisi poin-poin yang mewakili sejauh mana Desa Wlahar Wetan telah menerapkan aspek akuntabilitas, transparansi, dan partisipasi. 
Poin-poin penilaian tersebut diantaranya menilai modal sosial dalam desa seperti partisipasi masyarakat dalam musyawarah dan berapa kali musyawarah dilakukan. Selain itu penilaian juga dilakukan pada akses informasi dan komunikasi yang dimiliki desa seperti papan informasi desa, website, dan lainnya. Kemudian penggunaan Dana Desa dalam pelaksanaan pembangunan dan pemberdayaan masyarakat juga turut dinilai. Sejak adanya Dana Desa maka besaran indeks IDM di desa dituntut harus terus meningkat sebagai indikator bahwa penggunaan dan pengelolaan Dana Desa sudah sesuai.

Hal yang menarik bagi peneliti yaitu meskipun penerimaan Dana Desa yang lebih rendah dibandingkan desa lainnya namun Desa Wlahar Wetan terus berproses secara aktif dalam pengelolaan dan pemanfaatan Dana Desa serta komitmennya untuk mewujudkan clean government dan good local governance melalui Visi Desa. Berdasarkan hasil wawancara pra survei dengan Sekretaris Desa Wlahar Wetan dan pengamatan sementara yang dilakukan oleh peneliti yaitu Desa Wlahar Wetan sudah mulai menerapkan prinsip akuntabilitas, transparansi dan partisipasi dalam pengelolaan Dana Desa. Sehingga harapannya dengan hasil penelitian ini nanti dapat menganalisis sejauh mana penerapan prinsip-prinsip yang sudah dilakukan dan mampu menemukan sesuatu yang baru dari konsep good governance agar dapat dijadikan sebagai referensi konsep good governance yang selama ini kita ketahui khususnya di sektor pengelolaan keuangan tingkat desa.

\section{TINJAUAN PUSTAKA}

\section{Good Governance}

Dikutip dari Sedarmayanti (2012: 3) Governance berkembang semakin populer dengan sebutan kepemerintahan. Namun, makna kepemerintahan tersebut tidak hanya sebagai suatu kegiatan tetapi di dalamnya terdapat arti kepengurusan, pengelolaan, ada pengarahan, dan pembinaan dalam penyelenggaraan. Sedangkan praktik terbaiknya disebut atau good governance kepemerintahan yang baik. Dwipayana dan Eko dikutip dalam Syakrani (2009:122) juga menjelaskan bahwa governance merupakan konsep netral, yang bisa memformat model yang sehat (baik), sehingga muncul istilah good governance (tata kelola pemerintahan yang sehat). Sehingga governance dapat dikatakan merupakan suatu upaya dari pemerintah dalam menyelenggarakan suatu pemerintahan yang baik sesuai dengan ketentuan dan aturan yang berlaku. Praktik governance dalam penyelenggaraan pemerintahan terbaiknya dapat disebut dengan good governance.

\section{Prinsip-Prinsip Good Governance}

Dalam Kamus Besar Bahasa Indonesia kata prinsip memiliki makna yaitu "asas atau kebenaran yang menjadi pokok dasar dalam berpikir dan bertindak." Sehingga, dengan upaya menerapkan prinsip - prinsip pemerintahan yang baik (good governance) akan membantu negara untuk mewujudkan penyelenggaraan pemerintahan yang baik. Ganie-Rochman (2000) 
dikutip dalam Syakrani (2009: 132) mengembangkan 4 prinsip, yakni akuntabilitas, rule of law, informasi, dan transparansi. Prinsip-prinsip yang hampir sama juga dikemukakan Bhatta (1997) bahwa unsur utama governance yaitu akuntabilitas, transparansi, keterbukaan, dan rule of law.

Berikutnya UNDP (1997) dikutip dalam Mindarti (2016: 14) menyatakan bahwa prinsip dalam praktik penyelenggaraan kepemerintahan yang baik, meliputi Participation (partisipasi), Rule of law (aturan hukum), Transparency (transparansi), Responsiveness (daya tanggap), Consensus Orientation(orientasi konsensus), Equity (keadilan), Efficiency and effectiveness (efisiensi dan efektivitas), Accountability (pertanggungjawaban), Strategy vision (visi strategi). Dari berbagai prinsip-prinsip good governance tersebut, penelitian ini akan menggunakan tiga dari empat prinsip good governance menurut Sedarmayanti (2012: 7), yaitu akuntabilitas, transparansi, dan partisipasi. Seperti yang disimpulkan oleh Sedarmayanti bahwa empat prinsip atau prinsip utama tersebut yang dapat memberi gambaran administrasi publik yang bercirikan good governance.

\section{Prinsip Akuntabilitas}

Guy Peter (2000) menyebutkan bahwa terdapat tiga jenis akuntabilitas yaitu akuntabilitas keuangan, akuntabilitas administratif, dan akuntabilitas publik. Akuntabilitas publik menurut Mardiasmo (2002: 21) terdiri dari akuntabilitas vertikal dan horizontal dimana akuntabilitas vertikal merupakan bentuk pertanggungjawaban unit kerja kepada pemerintah daerah, pertanggungjawaban pemerintah daerah kepada pemerintah pusat, dan pemerintah pusat kepada Majelis Permusyawaratan Rakyat (MPR), sedangkan akuntabilitas horizontal merupakan bentuk pertanggungjawaban kepada masyarakat luas. Menurut Teguh (2004: 23) terdapat indikator atau cara yang dapat digunakan untuk menilai akuntabilitas yaitu ditandai dengan bagaimana tingkat pertanggungjawaban pemerintah dalam menjalankan tugas, apakah terdapat praktik KKN.

\section{Prinsip Transparansi}

Lalolo (2003: 13) mendefinisikan transparansi sebagai suatu prinsip yang dapat menjamin akses atau memberikan kebebasan bagi setiap orang untuk memperoleh informasi tentang penyelenggaraan pemerintahan dengan memberikan informasi mengenai kebijakan, proses pembuatan dan pelaksanaannya, serta hasil-hasil yang dicapai. Adapun pernyataan Kristiantem yang dikutip dalam Rahmawati (2015) menyebutkan bahwa transparansi dapat diukur melalui beberapa indikator yaitu, kesediaan dan aksesibilitas dokumen, kejelasan dan kelengkapan informasi, keterbukaan proses, kerangka regulasi yang menjamin transparansi.

\section{Prinsip Partisipasi}

Sedarmayanti (2012: 5) menyatakan bahwa makna prinsip partisipasi yang harus dikembangkan dalam mewujudkan kepemerintahan yang baik adalah setiap orang atau warga 
masyarakat, baik laki-laki maupun perempuan memiliki hak suara yang sama dalam proses pengambilan keputusan. Cohen dan Uphoff (dalam Siti Orene A.D, 2011: 61) memaknai bahwa partisipasi masyarakat dalam mewujudkan kepemerintahan yang baik tidak hanya pada tahap pengambilan keputusan, namun hampir pada setiap tahapan terdapat peran dan partisipasi dari masyarakat mulai dari tahap pengambilan keputusan hingga tahap evaluasi. Artinya, peran masyarakat sangat penting dalam setiap kegiatan dan program pemerintah.

\section{METODE PENELITIAN}

Metode penelitian yang digunakan dalam penelitian ini adalah metode kualitatif. asaran dalam penilitian ini yakni Pemerintah Desa Wlahar Wetan sebagai unit organisasi yang mengelola Dana Desa di Desa Wlahar Wetan yang berasal dari Anggaran Pendapatan dan Belanja Negara (APBN), Lembaga Desa di Desa Wlahar Wetan yaitu Badan Permusyawaratan Desa (BPD) Desa Wlahar Wetan, Perwakilan Kelompok Masyarakat di Desa Wlahar Wetan yaitu Kelompok Petani, Kelompok Perempuan atau PKK, Kelompok Pengrajin, dan Kelompok Disabilitas, serta Organisasi Pemerintah Daerah (OPD) yang berkaitan dengan pengelolaan Dana Desa di Kabupaten Banyumas meliputi Dinas Sosial dan Pemberdayaan Masyarakat Desa, Badan Keuangan Daerah, dan Kecamatan Kalibagor. Teknik pemilihan informan dalam penelitian ini menggunakan teknik purposive sampling dan snowball sampling. Ketiga teknik tersebut dilakukan secara terus menerus dan berulang selama waktu masih ada hingga datanya jenuh.

\section{HASIL DAN ANALISIS}

\section{Akuntabilitas}

Pemerintah Desa Wlahar Wetah telah berupaya melaksanakan akuntabilitas Dana Desa secara vertikal dan horizontal. Terkait dengan akuntabilitas vertikal, selama ini Pemerintah Desa Wlahar Wetan selalu tepat waktu dalam menginput laporan akuntabilitas Dana Desa dan keuangan desa ke aplikasi OM-SPAN dan Siskeudes yang merupakan aplikasi dari Kementerian Keuangan dan Kementerian Dalam Negeri untuk memudahkan sistem akuntabilitas yang dapat langsung diakses oleh Pemerintah Pusat. Ketepatan waktu dalam akuntabilitas Dana Desa ini mencerminkan bahwa tingkat penyerapan Dana Desa di Desa Wlahar Wetan sudah sesuai dengan target yang harus dicapai sesuai ketentuan Pemerintah Pusat. Informasi-informasi yang diinput ke dalam aplikasi OM-SPAN dan Siskeudes menerangkan kinerja Pemerintah Desa dalam pengelolaan Dana Desa karena berisi informasi tingkat penyerapan, hasil kegiatan, realisasi, yang digunakan untuk Pemerintah Pusat untuk menilai progres perkembangan Desa Wlahar Wetan sebagai desa yang sudah menerima Dana Desa.

Akuntabilitas secara vertikal di Desa Wlahar Wetan ini dapat berjalan tentunya tidak terlepas dari kemampuan Pemerintah Desa yaitu Kepala Desa dan Perangkat Desa. Jika kita 
lihat pada tingkat pendidikan terakhir Perangkat Desa dan Kepala Desa hanya ada 1 (satu) perangkat desa yang tingkat pendidikan terakhirnya SMP sedangkan yang lainnya yaitu SMA, D3, dan S1. Artinya, selain sudah sesuai dengan peraturan UU No. 6 Tahun 2014 tentang Desa mengenai tingkat pendidikan Perangkat Desa hal ini juga menunjukkan bahwa sumber daya manusia yang dimiliki Desa Wlahar Wetan sudah mumpuni. Kemampuan Perangkat Desa menjadi hal yang penting dalam mewujudkan tata kelola keuangan yang baik karena menurut hasil studi Astuti dan Yulianto (2016) bahwa untuk menerapkan prinsip-prinsip good governance ternyata hambatan terbesar dalam mewujudkan good governance adalah Perangkat Desa di Pemerintahan Desa yang belum terlatih dalam mengelola keuangan desa dengan tata cara yang baik.

Akuntabilitas publik ini tidak sekedar tanggung jawab antara pemerintahan yang di bawah dengan pemerintahan yang di atasnya tetapi juga tanggung jawab kepada masyarakat secara luas. Masyarakat perlu mengetahui apakah kebijakan pemerintah benar-benar menghasilkan kinerja sesuai dengan yang diharapkan atau tidak. Berdasarkan hasil penelitian dokumen pertanggungjawaban APBDes dilaporkan kepada masyarakat melalui Perdes di setiap akhir tahun anggaran. Kondisi ini sejalan dengan Cunningham \& Harris (2000: 159-162) menyatakan bahwa kinerja laporan keuangan yang baik, menunjukan bahwa pelaksanaan suatu program mampu mewujudkan akuntabilitas publik. Berdasarkan hasil penelitian dan pengamatan Desa Wlahar Wetan ini belum pernah mendapat sanksi bahkan tersandung kasus yang berkaitan dengan pengelolaan Dana Desa. Administrasi dan akuntabilitas Desa Wlahar Wetan dinilai tertib dan rapih.

\section{Transparansi}

Pemerintah Desa Wlahar Wetan berkomitmen dalam keterbukaan informasi mengenai pengelolaan Dana Desa sebagai bagian dari proses transparansi. Hal ini ditunjukkan dengan menyediakan fasilitas seperti dapat mendatangi Kantor Sekretariat Desa, mengirim surat elektronik di pemdes@wlaharwetan.desa.id atau mengisi formulir permohonan informasi di website dea. Pemerintah Desa bersikap berupaya terbuka terhadap segala informasi yang berkaitan dengan pengelolaan Dana Desa selama memang informasi yang dibutuhkan merupakan informasi yang boleh diakses secara umum. Hal tersebut senada dengan konsep transparansi menurut Lalolo (2003: 13) dimana transparansi sebagai suatu prinsip yang dapat menjamin akses atau memberikan kebebasan bagi setiap orang untuk memperoleh informasi tentang penyelenggaraan pemerintahan dengan memberikan informasi mengenai kebijakan, proses pembuatan dan pelaksanaannya, serta hasil-hasil yang dicapai.

Dengan adanya transparansi ini masyarakat bisa membandingkan nilai rupiah yang dilaporkan dengan wujud pembangunan fisik yang ada di lapangan. Jika sudah sesuai dengan yang dilaporkan tentu tidak akan ada permasalahan. Seperti halnya di Desa Wlahar Wetan, 
kemudahan dalam mengakses informasi diwujudkan dengan disediakannya media-media transparansi seperti baliho Info Grafik APBDes (anggaran Dana Desa terakumulasi di sini) yang dipasang di halaman kantor balai desa dimana media ini merupakan media transparansi yang wajib ada bagi setiap desa, kemudian juga mengadakan sosialiasai kepada masyarakat di pertemuan-pertemuan dengan membagikan brosur, dan memasang papan proyek ketika ada kegiatan pembangunan di desa dengan penggunaan Dana Desa dimana semua informasi tertera di situ mulai dari besaran anggaran dan waktu pelaksanaan sehingga masyarakat dapat melihatnya. Selain media-media yang telah disebutkan sebelumnya, Desa Wlahar Wetan juga aktif menggunakan media digital seperti website desa dan social media Instagram, Facebook, dan Twitter sebagai media transparansi pengelolaan Dana Desa dan kegiatan desa dimana sasarannya lebih kepada masyarakat di luar Desa Wlahar Wetan. Media digital seperti ini mudah diakses juga oleh masyarakat desa tetapi jarang diakses karena sudah cukup dengan media yang tersedia langsung di desa.

Menurut hasil studi Zulkifli, Rahman, Mohamed, et al (2016) akhirnya, untuk menjalankan tata kelola yang baik, Pemerintah Daerah harus transparan. Hal ini dapat dicapai dengan menjelaskan anggaran yang diperluas melalui pendapatan yang dikumpulkan dan menginformasikan kepada publik bagaimana uang yang dikumpulkan dihabiskan untuk memberi manfaat kepada penduduk setempat. Akan tetapi transparansi yang dilakukan oleh Pemerintah Desa Wlahar Wetan belum luas sampai pada dampak dari kegiatan yang menggunakan Dana Desa.

\section{Partisipasi}

Pemerintah Desa Wlahar Wetan senantiasa berupaya untuk aktif melibatkan masyarakat dalam proses pengelolaan Dana Desa. Pemerintah desa menyediakan ruang bagi masyarakat untuk terlibat dalam perencanaan penggunaan Dana Desa melalui media seperti pertemuan atau musyawarah desa. Pemerintah Desa melibatkan unsur masyarakat yang ada di desa seperti kelompok petani, kelompok perempuan, kelompok pemuda, masyarakat miskin, hingga kelompok disabilitas. Pemerintah Desa menstimulasi keterlibatan masyarakat desa mulai dari tingkat paling bawah yaitu Musyawarah Dusun, Musyawarah Desa, dan juga Musyawarah Rencana Pembangunan Desa. Keterlibatan masyarakat merupakan suatu hal yang sangat penting karena Dana Desa ini sesuai dengan tujuannya untuk kesejahteraan masyarakat sehingga partisipasi masyarakat harus digerakan dan diakomodir oleh Pemerintah Desa demi tercapainya tujuan tersebut.

Terkait pentingnya sifat proaktif pemerintah dalam partisipasi masyarakat sesuai dengan hasil studi Zulkifli, Rahman, Mohamed, et al (2016) yang juga menemukan bahwa tata pemerintahan yang baik dan partisipasi publik saling terkait satu sama lain. Namun, karena masyarakat memiliki persepsi negatif terhadap Pemerintah Daerah, masalah ini dapat 
menyebabkan rendahnya keterlibatan dalam program mereka. Pemerintah Daerah harus bersahabat dengan publik dan menjelaskan fungsinya kepada publik. Seharusnya juga ada sesi dialog dengan publik mengenai masalah lokal. Pemerintah daerah harus mengatur program untuk meningkatkan hubungan yang baik dengan penduduk setempat. Pemerintah Daerah juga dapat mengambil inisiatif untuk menghabiskan waktu mereka dan mengirim perwakilan untuk melakukan sesi khusus seperti sesi terbuka dengan penduduk setempat sehingga mereka tahu bahwa suara mereka didengar.

Permendagri No. 20 Tahun 2018 menegaskan bahwa pelaksanaan kegiatan pembangunan di desa dilakukan dengan melibatkan partisipasi masyarakat untuk memperluas kesempatan kerja dan pemberdayaan masyarakat setempat. Selaras dengan hal ini, Pemerintah Desa Wlahar Wetan aktif melibatkan masyarakat dalam pelaksanaan kegiatan pembangunan di desa. Pemerintah Desa menggunakan tenaga kerja yang ada di desa untuk pemberdayaan masyarakat dan memberikan lapangan pekerjaan. Keterlibatan masyarakat juga terlihat dalam pengelolaan BUMDES di desa Wlahar Wetan. Di dalam pengelolaan BUMDES terdapat penyertaan modal yang berasal dari dana desa. Melihat BUMDES "Karya Kusuma Mandiri” yaitu BUMDES di Desa Wlahar Wetan yang terus berkembang menunjukkan bahwa kerja sama antara Pemerintah Desa dengan masyarakat desa berjalan dengan baik. Pemerintah berhasil menggerakan pemberdayaan masyarakat hingga saat ini di bawah naungan BUMDES berhasil dibangun minimarket atau Warung Kampung di desa dan tempat wisata Bumi Tambangan hasil dari gagasan masyarakat Desa Wlahar Wetan.

Berdasarkan hasil penelitian Pemerintah Desa Wlahar Wetan belum melibatkan masyarakat sampai pada tahap evaluasi. Padahal dengan keterlibatan masyarakat pada tahapan evaluasi ini dapat menjadikan parameter apakah sasaran pembangunan telah tercapai seperti hasil studi Rustiarini (2016) dalam pengelolaan Dana Desa di Provinsi Bali kelemahannya adalah tidak adanya parameter serta sasaran pembangunan yang digunakan untuk mengukur sejauh mana pelaksanaan program kerja berhasil. Cohen dan Uphoff (dalam Siti Orene A.D, 2011: 61) juga memaknai bahwa partisipasi masyarakat dalam mewujudkan kepemerintahan yang baik tidak hanya pada tahap pengambilan keputusan, namun hampir pada setiap tahapan terdapat peran dan partisipasi dari masyarakat mulai dari tahap pengambilan keputusan hingga tahap evaluasi.

\section{KESIMPULAN}

Akuntabilitas dalam pengelolaan Dana Desa di Desa Wlahar Wetan dapat dilihat dari kemampuan pemerintah Desa Wlahar Wetan untuk menginput laporan akuntabilitas pengelolaan Dana Desa ke aplikasi OM-SPAN dan Siskeudes dengan tepat waktu. Pemerintah Desa Wlahar Wetan juga mempertanggungjawabkan pengelolaan Dana Desa kepada 
masyarakat dengan membuat Perdes APBDes di setiap akhir tahun dimana Perdes ini diketahui dan disahkan oleh Pemerintah Desa bersama dengan Badan Permusyawaratan Desa (BPD) sebagai wakil dari masyarakat desa. Namun, penilaian prosedur akuntabilitas sejauh ini hanya melihat pada ketepatan waktu dalam melaporkan penggunaan Dana Desa saja dan belum melakukan pengawasan mulai dari perencanaa, pelaksanaan, hingga evaluasi penggunaan Dana Desa. Sanksi terkait pelanggaran akuntabilitas juga belum diterapkan secara tegas. Untuk Desa Wlahar Wetan sejauh ini belum pernah tersandung kasus yang berkaitan dengan kasus administrasi ataupun pidana dalam pengelolaan Dana Desa. Transparansi dalam pengelolaan Dana Desa yang telah dilakukan oleh Pemerintah Desa Wlahar Wetan sennatiasa siap untuk memberikan informasi mengenai Dana Desa di Desa Wlahar Wetan kepada semua pihak selama memang informasi yang diminta merupakan infromasi yang boleh diakses siapapun dan bukan merupakan informasi atau data yang dikecualikan. Prinsip Pemerintah Desa untuk selalu terbuka dengan informasi pengelolaan Dana Desa diikuti dengan media transparansi yang disediakan baik yang mudah diakses oleh masyarakat desa itu sendiri maupun masyarakat di luar desa Wlahar Wetan. Tetapi, transparansi yang dilakukan oleh Pemerintah Desa Wlahar Wetan masih sebatas anggaran dan realisasinya saja dan belum melakukan transparansi mengenai dampak dari kegiatan baik itu yang positif atau negatif agar bisa dijadikan evaluasi bersama. Partisipasi masyarakat dalam pengelolaan Dana Desa di Desa Wlahar Wetan dapat dilihat dari upaya Pemerintah Desa Wlahar Wetan untuk senantiasa melibatkan masyarakat dalam pengelolaan Dana Desa mulai dari perencanaan anggaran juga pada pelaksanaan kegiatan. Pemerintah Desa memberikan ruang bagi masyarakat untuk terlibat dalam perencanaan dari tingkat RT, RW, Musyawarah Dusun, Musyawarah Desa, dan Musyawarah Rencana Pembangunan Desa untuk menyampaikan ide, gagasan, dan kendala yang dialami di wilayahnya. Pemerintah Desa Wlahar Wetan juga melibatkan masyarakat dalam pelaksanaan kegiatan dengan menerapkan prinsip swakelola. Namun, masyarakat belum dilibatkan pada tahapan evaluasi dari kegiatan yang menggunakan Dana Desa.

\section{DAFTAR PUSTAKA}

Buku:

Mardiasmo. 2002. Akuntansi Sektor Publik. Yogyakarta: Penerbit Andi

Mindarti, Lely Indah. 2016. Aneka Pendekatan dan Teori Dasar Aministrasi Publik. Malang: Universitas Brawijaya Press.

Sedarmayanti. 2012. Good Governance (Kepemerintahan yang baik) Bagian Kedua Edisi Revisi. Bandung: Penerbit Mandar Maju.

Syakrani dan Syahriani. 2009. Implementasi Otonomi Daerah dalam Perspektif Good Governance. Yogyakarta: Pustaka Pelajar. 
Jurnal Ilmiah:

Astuti, T.P. and Yulianto, Y., 2016. Good Governance Pengelolaan Keuangan Desa Menyongsong Berlakunya Undang-Undang No. 6 Tahun 2014.Berkala Akuntansi dan Keuangan Indonesia, 1(1), pp.1-14.

Cunningham, G.M. and Harris, J.E., 2001. A Heuristic Framework For Accountability Of Governmental Subunits. Public Management Review, 3(2), pp.145-165.

Rahmawati, Eti Nur. 2015. Hubungan Penerapan Prinsip Transparansi Dan Akuntabilitas Dengan Pengelolaan Alokasi Dana Desa (ADD) (Studi Kasus Desa Candi Mas, Kecamatan Abung Selatan, Lampung Utara). Jurusan Ilmu Pemerintahan. Universitas Lampung.

Rustiarini, N.W., 2016. Good Governance dalam Pengelolaan Dana Desa. Proceeding SNA Lampung, 24.

Zulkifli, N., Rahman, S., Nurudin, S.M., Hamik, S.A. and Hashim, R., 2016.. Managing public perception towards local government administration. International Journal of Public Policy and Administration Research, 3(2), pp.14-20 